\title{
METABOLIT SEKUNDER DAN EFEK PENYEMBUHAN LUKA SAYAT EKSTRAK ETANOL BUAH PANDAN DURI (Pandanus tectorius Soland) PADA TIKUS PUTIH GALUR WISTAR (Rattus norvegicus)
}

\author{
Nur Aida Febriana*, Aditya Fridayanti, Arsyik Ibrahim \\ Laboratorium Penelitian dan Pengembangan FARMAKA TROPIS Fakultas Farmasi \\ Universitas Mulawarman, Samarinda, Kalimantan Timur \\ *Email: nuraida.febriana.nf@gmail.com
}

\begin{abstract}
ABSTRAK
Penelitian ini mengenai efek penyembuhan luka ekstrak etanol buah pandan duri (Pandanus tectorius Soland). Tujuan penelitian ini untuk mengetahui jumlah rendemen, kandungan metabolit sekunder dan efek penyembuhan luka dari ekstrak etanol buah pandan duri (pandanus tectorius Soland) pada tikus putih. Penelitian ini dilakukan dengan cara membuat luka sepanjang $2 \mathrm{~cm}$ pada hewan coba yang telah dibagi dalam 5 kelompok perlakuan, yaitu kontrol negatif, kontrol positif, ekstrak buah pandan duri 2,5\%, ekstrak buah pandan duri 3,75\% dan ekstrak buah pandan duri 5\%. Pengamatan luka dilakukan selama 10 hari. Hasil pengujian menunjukkan ekstrak etanol buah pandan duri memiliki rendemen sebanyak 17,62\% dan dengan kandungan metabolit sekunder berupa fenol, steroid dan alkaloid. Hasil pengukuran diperoleh rata-rata panjang luka pada konsentrasi $2,5 \%$ sebesar 0,878 , konsentrasi $3,75 \%$ sebesar 0,685 dan konsentrasi $5 \%$ yaitu 0,761 . Berdasarkan hasil analisis statistik menggunakan ANAVA (Analysis of Variant) dua arah dan uji lanjutan Perbandingan Berganda Duncan menunjukkan bahwa ekstrak etanol buah pandan duri dengan konsentrasi 3,75\% efektif dalam menyembuhkan luka pada tikus dan tidak terdapat perbedaan yang signifikan dibandingkan dengan Bioplacenton ${ }^{\circledR}$.
\end{abstract}

Kata Kunci : Ekstrak, buah pandan duri, penyembuhan luka, tikus putih

\begin{abstract}
This study about the wound healing effect of ethanol extract of thorn pandanus fruit (Pandanus tectorius Soland). The purpose of this study is to find the amount of yield, contains secondary metabolites and wound healing effect of the ethanol extract pandanus fruit (pandanus tectorius Soland) in mice. This research was done by making wound 2-cm on tested animals that have been divided into 5 groups, ie negative control, positive control, thorn pandanus fruit extract $2.5 \%$, pandanus fruit extract $3.75 \%$ spines and thorns pandanus fruit extract 5\%. Observations was conducted made during the 10-day. The test results showed the ethanol extract thorn pandanus fruit had a yield as much as $17.62 \%$ and the content of secondary metabolites such as phenols, steroids and alkaloids. Results of measurement obtained average length of the wound at a concentration of $2.5 \%$ amounting to $0.878,3.75 \%$ concentration of 0.685 and a concentration of $5 \%$ is 0.761 . Based on the results of statistical analysis using ANOVA (Analysis of Variant) two-way and advanced test Duncan's Multiple Comparisons showed that the ethanol extract with a concentration of $3.75 \%$ effective in healing wounds in rats and there was no significant difference compared with Bioplacenton ${ }^{\circledR}$.
\end{abstract}


Keywords : Extract, thorn pandanus fruit, wound healing, white rats

\section{PENDAHULUAN}

Luka adalah hilang atau rusaknya sebagian jaringan tubuh (R. Sjamsuhidajat dan Wim de Jong, 2004). Luka sering terjadi dalam aktivitas sehari-hari dan dapat terjadi dimana saja dan kapan saja. Biasanya luka yang terjadi bervariasi bentuk dan dalamnya sesuai dengan benda yang mengenainya. Jika tidak diobati, luka dapat menyebabkan infeksi.

Luka merupakan salah satu pembunuh utama pada anak-anak di seluruh dunia dan merupakan penyebab pada sekitar 950.000 kematian pada anak-anak dan remaja dibawah 18 tahun pada setiap tahunnya. Sebanyak 90\% dari semua kasus tersebut adalah luka yang tidak disengaja. Secara keseluruhan, lebih dari 95\% dari seluruh kematian karena luka pada anak-anak terjadi di negara dengan pendapatan rendah dan sedang (WHO, 2008).

Penanganan luka harus dilakukan dengan baik karena dapat menimbulkan komplikasi yang meliputi infeksi, hematom, seroma, perdarahan, dehiscence (terjadinya lubang akibat lepasnya lapisan luka operasi, yang dapat terjadi sebagian, di permukaan, atau di seluruh lapisan dengan robekan total), eviscerasi (ekstrusio alat viscera keluar dari tubuh, khususnya melalui suatu insisi bedah), keloid, dan jaringan parut hipertrofik.

Pengobatan alternatif telah lama dikenal masyarakat sebagai pengganti pengobatan modern. Hingga saat ini, masih banyak masyarakat di Indonesia yang menggunakan pengobatan alternatif untuk menanggulangi berbagai masalah kesehatan tidak terkecuali obat luka. Bahan pengobatan alternatif biasanya didapat dari tumbuh-tumbuhan maupun hewan.

Salah satu tanaman yang dimanfaatkan untuk menyembuhkan luka adalah rasau atau pandan duri, yang berdasarkan penelitian $(\mathrm{Xu}, 2012)$ yang menyatakan bahwa buah dari Pandanus tectorius mengandung senyawa metabolit sekunder berupa vanillin (antioksidan) trans-etil cafeat (antiinflamasi), tangeretin (menurunkan kolesterol) dan naringenin (antivirus). Sedangkan secara empiris suku dayak di Desa Kereng Bangkirai, Kalimantan Tengah sering memanfaatkan tanaman ini khususnya pada bagian humbut (batang dalam). Mereka menganggap batang dalam pandan duri membuat luka cepat kering. Berdasarkan kesamaan bentuk tanaman dan pendekatan metabolit sekunder yang ada, dengan demikian saya tertarik untuk meneliti apakah buah pandan duri juga berpotensi sebagai obat luka.

Tujuan dalam penelitian ini yaitu mngetahui jumlah rendemen ekstrak etanol buah pandan duri (Pandanus tectorius Soland), mengetahui kandungan metabolit sekunder dan mengetahui aktivitas ekstrak etanol buah pandan duri (Pandanus tectorius Soland) dalam menyembuhkan luka serta konsentrasi terbaik ekstrak etanol buah pandan duri (Pandanus tectorius Soland) yang dapat menyembuhkan luka.

\section{METODE PENELITIAN}

\section{Bahan}

Bahan yang digunakan dalam penelitian ini adalah buah pandan duri (Pandanus tectorius Soland), Etanol 96\%, Bioplacenton ${ }^{\circledR}$, Lidocain, salin normal dan kasa steril.

\section{Peralatan}

Peralatan yang digunakan adalah gelas kimia, pisau bedah, labu ukur, pencukur bulu, timbangan analitik, pinset, Rotary evaporator dan waterbath. 


\section{Penyiapan Sampel}

Sampel yang digunakan dalam penelitian ini adalah buah pandan duri yang terlebih dahulu dibuat simplisia. Kemudian simplisia buah pandan duri diekstraksi menggunakan pelarut etanol.

\section{Pembuatan Ekstrak Etanol Buah Pandan Duri}

Pembuatan ekstrak dilakukan dengan mengekstraksi sampel secara maserasi menggunakan pelarut etanol 96\%. Simplisia buah pandan duri dimasukkan ke dalam wadah toples kaca, lalu ditambahkan pelarut etanol 96\% hingga sampel terendam seluruhnya dan diaduk. Wadah kemudian ditutup dan dibiarkan selama 3 hari sambil sesekali diaduk setiap 24 jam. Hasil ekstraksi kemudian disaring menggunakan kertas saring sehingga diperoleh filtrat dan residunya. Residu penyaringan dimaserasi kembali (remaserasi) hingga filtrat menjadi bening. Filtrat diuapkan menggunakan rotary evaporator pada suhu $55^{\circ} \mathrm{C}$ hingga hasil penguapan ekstrak cair menjadi $1 / 4$ dari volume awal. Ekstrak kental kemudian diuapkan pada suhu kamar hingga seluruh sisa pelarut menguap dan diperoleh ekstrak kering buah pandan duri.

\section{Identifikasi Metabolit Sekunder}

Identifikasi metabolit sekunder dilakukan secara kualitatif yakni dengan mengamati perubahan warna maupun terjadinya endapan setelah penambahan reagen kimia tertentu. Golongan metabolit sekunder yang diuji adalah alkaloid, fenol, flavonoid, saponin, steroid, dan tanin.

Identifikasi alkaloid dilakukan dengan penambahan $\mathrm{HCl} 2 \%$ kemudian dibagi dalam 2 tabung. Tabung 1 ditambahkan pereaksi Dragendorf dan tabung 2 ditambahkan pereaksi Meyer. Jika terbentuk endapan merah bata (tabung 1) dan terbentuk endapan putih (tabung 2) maka positif mengandung alkaloid. Identifikasi senyawa fenol dilakukan dengan penambahan $\mathrm{FeCl}_{3}$. Hasil positif jika terjadi perubahan warna menjadi hijau atau biru kehitaman. Identifikasi flavonoid menggunakan metanol, $\mathrm{HCl}$ pekat, dan pita $\mathrm{Mg}$. Positif mengandung flavonoid jika terbentuk warna jingga. Identifikasi saponin dilakukan dengan penambahan aquades lalu dikocok kuat dan ditambahkan HCl. Jika buih stabil maka positif mengandung saponin. Identifikasi steroid dengan penambahan asam asetat anhidrat, kloroform, dan asam sulfat pekat. Hasil positif dengan adanya cincin merah kecoklatan atau ungu dibatas kedua larutan. Identifikasi tanin dengan penambahan gelatin dan $\mathrm{FeCl}^{3}$. Hasil positif jika terbentuk endapan putih setelah penambahan gelatin dan hijau atau biru kehitaman setelah penambahan $\mathrm{FeCl}_{3}$ (Depkes RI., 1996).

\section{Pembuatan Variasi Konsentrasi Ekstrak}

Uji pendahuluan dilakukan untuk menentukan konsentrasi yang signifikan dalam penyembuhan luka sayat, kemudian konsentrasi tersebut diturunkan dan dinaikkan untuk melihat perbandingan konsentrasi ektrak yang efektif. Variasi konsentrasi ekstrak dalam bentuk gel dengan menggunakan air suling dan $\mathrm{Na}$ CMC kemudian dibuat seri konsentrasi ekstrak yaitu 2,5\%;3,75\% dan $5 \%$.

\section{Penyiapan Hewan Uji}

Hewan uji yang digunakan dalam penelitian ini adalah tikus putih sebanyak 25 ekor dengan berat badan 180-200 gram dan dibagi dalam 5 kelompok uji yaitu 3 kelompok uji ekstrak; kontrol negatif; dan kontrol positif masing-masing terdiri dari 5 ekor tikus. tikus terlebih dahulu diaklimatisasi selama seminggu di kandang hewan Fakultas Farmasi Universitas Mulawarman dengan tujuan agar dapat beradaptasi dengan lingkungan baru dan meminimalisasi efek stress. 


\section{Pembuatan Luka dan Perlakuan pada Hewan Coba}

Hewan coba ditimbang terlebih dahulu, kemudian bulu di sekitar daerah yang akan dilukai dicukur dan dibersihkan menggunakan kapas beralkohol 70\%. Perlukaan dilakukan setelah sebelumnya tikus dianastesi menggunakan Lidocain. Kemudian dilakukan perlukaan didaerah punggung menggunakan bisturi dengan panjang luka $2 \mathrm{~cm}$ dan kedalaman $0,25 \mathrm{~cm}$. berikut :

Perlakuan dan pengamatan atau pengumpulan data pada penelitian ini ialah sebagai

a. Sebelum perlakuan, ditentukan galur dari hewan coba yang digunakan

b. Setelah dibuat luka pada tikus, kemudian diukur panjang luka awal sebelum dilakukan perlakuan.

c. Masing-masing tikus putih diberi perlakuan sebagai berikut :

Perlakuan A : Luka diberi Na CMC (kontrol negatif)

Perlakuan B : Luka diberi Bioplacenton ${ }^{\circledR}$ (kontrol positif)

Perlakuan C : Luka diberi ekstrak buah pandan duri 2,5\%

Perlakuan D : Luka diberi ekstrak buah pandan duri 3,75\%

Perlakuan E : Luka diberi ekstrak buah pandan duri 5\%

d. Kemudian dilakukan pengamatan selama 10 hari untuk melihat panjang penyembuhan luka.

e. Na CMC, Bioplacenton dan ekstrak diberikan dengan mengoleskan secara merata pada daerah luka dua kali sehari

f. Pengamatan pada luka dilakukan sebelum pemberian dan sesudah perlakuan sampai menunjukkan adanya tanda-tanda kesembuhan dengan cara mengukur panjang luka.

\section{Analisis Data}

Pengukuran rata-rata panjang luka sayat dilakukan dengan Px $(1,2,3,4,5)$ yaitu panjang luka sayat setiap replikasi perlakuan.

$$
P x=\frac{p x(1)+p x(2)+p x(3)+p x(4)+p x(5)}{5} \text { untuk rata-rata panjang luka sayat }(\mathrm{cm}) .
$$

Secara statistik data dianalisis dengan metode ANOVA (Analysis Of Variant) dengan $\alpha$ 0,05 atau 5\%, dengan rumus $\mathrm{P} \%=\frac{p o-p x}{p o} \mathrm{x} 100 \%$, dimana $\mathrm{P} \%$ untuk persentase penyembuhan luka. Bila hasilnya signifikan maka dapat dilakukan uji lanjutan yang sesuai. Selanjutnya hasil penyembuhan luka dari konsentrasi terbaik ekstrak dibandingkan dengan kontrol positif (Bioplacenton ${ }^{\circledR}$ ) menggunakan uji-t.

\section{HASIL DAN PEMBAHASAN}

\section{Rendemen Ekstrak Etanol Buah Pandan Duri}

Simplisia kering buah pandan duri sebanyak 248 gram dimaserasi dengan menambahkan pelarut ke dalam wadah hingga seluruh sampel terendam seluruhnya. Hasil ekstraksi kemudian disaring. Filtrat yang diperoleh dievaporasi hingga diperoleh ekstrak kental. Ekstrak kental kembali diuapkan hingga seluruh pelarut menguap dan diperoleh ekstrak kering. Dari hasil penguapan diperoleh ekstrak kering sebanyak 43,7 gram. Data persentase rendemen ekstrak buah pandan duri dapat dilihat pada tabel 1 . 
Tabel 1. Rendemen Ekstrak Etanol Buah Pandan Duri

\begin{tabular}{cc}
\hline Sampel & Jumlah (gram atau \%) \\
\hline Simplisia kering & 248 gram \\
Ekstrak & 43,7 gram \\
\hline Persentase rendemen & $17,62 \%$ \\
\hline
\end{tabular}

\section{Metabolit Sekunder Ekstrak Etanol Buah Pandan Duri}

Metabolit sekunder merupakan senyawa yang disintesis oleh suatu makhluk hidup bukan untuk memenuhi kebutuhan dasarnya, tetapi untuk mempertahankan eksistensinya dalam berinteraksi dengan lingkungan hidup seperti mempertahankan diri dari hama penyakit atau untuk berkompetisi dengan makhluk hidup lain di sekitarnya. Hasil identifikasi metabolit sekunder ekstrak etanol beras ketan hitam dapat dilihat pada tabel 2.

Tabel 2. Metabolit Sekunder Ekstrak Etanol Beras Ketan Hitam

\begin{tabular}{ccc}
\hline Metabolit Sekunder & Hasil $(+/-)$ & Keterangan \\
\hline Alkaloid & + & Endapan merah bata \\
Fenol & + & Larutan kehitaman \\
Flavonoid & - & Larutan kecoklatan \\
Saponin & - & Tidak terbentuk buih \\
Steroid & + & Terbentuk cincin merah kecoklatan \\
Tanin & - & Larutan kekuningan \\
\hline
\end{tabular}

Keterangan:

$(-) \quad$ : tidak teridentifikasi metabolit sekunder

(+) : teridentifikasi metabolit sekunder

Berdasarkan tabel 2 diketahui ekstrak etanol buah pandan duri mengandung senyawa metabolit sekunder golongan alkaloid, fenol dan steroid. Uji kandungan senyawa kimia kimia ekstrak etanol buah pandan duri dilakukan untuk mengetahui senyawasenyawa yang terlarut setelah proses ekstraksi simplisia dengan pelarut etanol, dengan diketahuinya kandungan senyawa dalam ekstrak maka dapat diperkirakan mekanisme kerja dari ekstrak etanol buah pandan duri dalam penyembuhan luka.

\section{Aktivitas Penyembuhan Luka Ekstrak Buah Pandan Duri}

Dari hasil pengamatan terdapat panjang luka pada tikus kontrol maupun tikus perlakuan menunjukkan penyembuhan luka. Pada tikus dengan perlakuan ekstrak mengalami kesembuhan yang lebih cepat dibadingkan dengan kontrol negatif. Hal ini terlihat pada hari ke-2 dimana pada kelompok hewan perlakuan telah mengalami pengurangan panjang luka sedangkan pada kontrol negatif panjang luka masih $2 \mathrm{~cm}$. Pengamatan pada hari ke-10 pada tikus perlakuan sudah mengalami penyembuhan luka secara menyeluruh sedangkan pada tikus kontrol belum terjadi penutupan luka secara menyeluruh. 


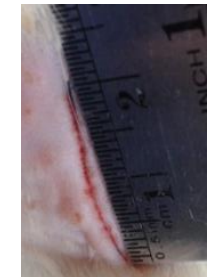

A)

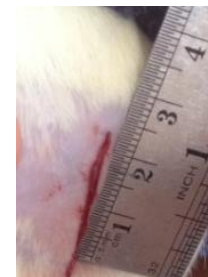

B)

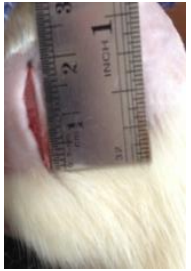

C)

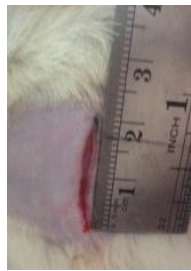

D)

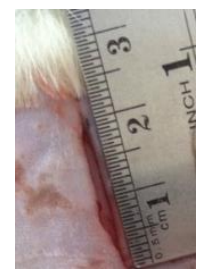

E)

Gambar 1. Gambaran makroskopik luka hari ke-0 dari kelima kelompok perlakuan. A) kontrol negatif, B) kontrol positif, C) ekstrak 2,5\%, D) ekstrak 3,75\%, dan E) ekstrak 5\%

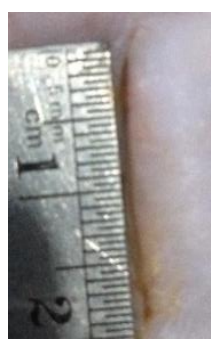

A)

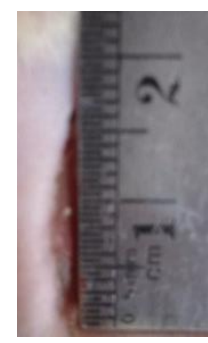

B)

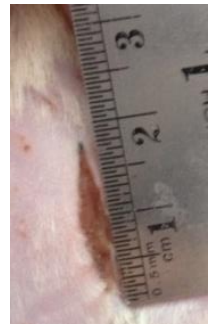

C)

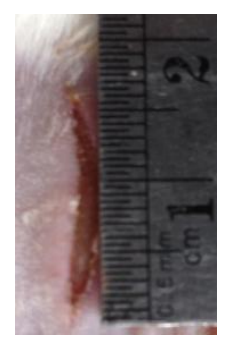

D)

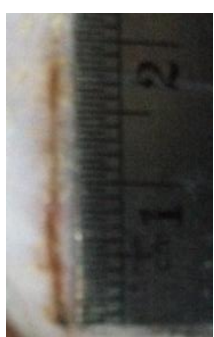

E)

Gambar 2. Gambaran makroskopik luka hari ke-2. A) kontrol negatif, B) kontrol positif, C) ekstrak 2,5\%, D) ekstrak 3,75\%, dan E) ekstrak 5\%

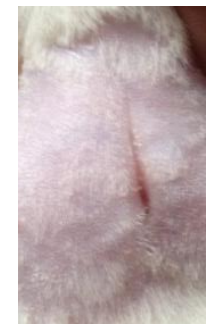

A)

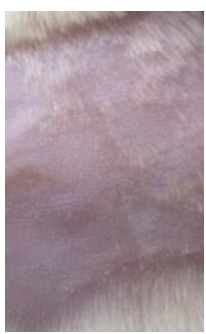

B)

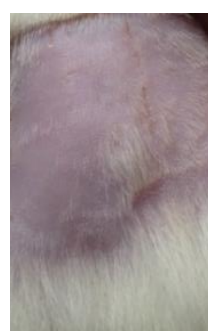

C)

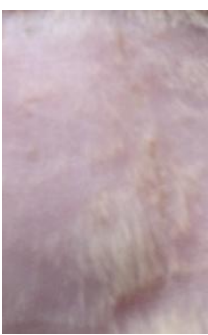

D)

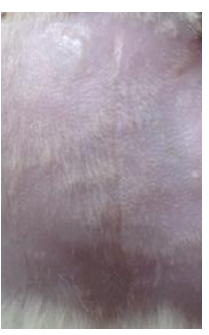

E)

Gambar 3. Gambaran makroskopik luka hari ke-10. A) kontrol negatif, B) kontrol positif, C) ekstrak 2,5\%, D) ekstrak 3,75\%, dan E) ekstrak 5\%

Hasil pengukuran rata-rata panjang luka terhadap proses penyembuhan luka sayat pada hewan uji selama 10 hari pengamatan dapat dilihat pada tabel 3. 
Tabel 3. Hasil pengukuran Panjang Luka Tikus Putih Hari ke-0 sampai hari ke-10

\begin{tabular}{cccccc}
\hline \multirow{2}{*}{$\begin{array}{c}\text { Hari ke } \\
(\mathrm{cm})\end{array}$} & $\begin{array}{c}\text { Na CMC } \\
\text { (kontrol } \\
\text { negatif) }\end{array}$ & $\begin{array}{c}\text { Bioplacenton } \\
\text { (kontrol } \\
\text { positif) }\end{array}$ & $\begin{array}{c}\text { Ekstrak } \\
2,5 \%\end{array}$ & $\begin{array}{c}\text { Ekstrak } \\
3,75 \%\end{array}$ & Ekstrak 5\% \\
\hline 0 & 2 & 2 & 2 & 2 & 2 \\
1 & 2 & 2 & 1.91 & 2 & 2 \\
2 & 2 & 1.77 & 1.88 & 1.84 & 1.9 \\
3 & 1.59 & 1.13 & 1.65 & 1.44 & 1.61 \\
4 & 1.17 & 0.38 & 1.21 & 0.93 & 1.11 \\
5 & 0.83 & 0.32 & 0.94 & 0.42 & 0.34 \\
6 & 0.58 & 0 & 0.41 & 0.1 & 0.22 \\
7 & 0.38 & 0 & 0.41 & 0.06 & 0.16 \\
8 & 0.26 & 0 & 0.25 & 0.06 & 0.16 \\
9 & 0.14 & 0 & 0.12 & 0 & 0.11 \\
10 & 0.13 & 0 & 0 & 0 & 0 \\
\hline
\end{tabular}

Untuk membandingkan presentase penyembuhan luka antar perlakuan, maka panjang luka untuk tiap luka dipresentasekan terhadap panjang luka sebelum perlakuan (hari ke 0) dianggap 0,00\% dengan demikian dapat dikatakan bahwa persentase penyembuhan luka sebelum perlakuan pada semua subjek penelitian ialah sama. Hasil persentase penyembuhan luka masing-masing perlakuan dapat dilihat pada tabel 4 .

Tabel 4. Persentase penyembuhan luka setelah perlakuan dengan kelompok kontrol negatif dan positif serta ekstrak buah pandan duri 2,5\%; 3,75\% dan $5 \%$.

\begin{tabular}{cccccc}
\hline Hari ke & $\begin{array}{c}\text { Kontrol } \\
\text { negatif }\end{array}$ & $\begin{array}{c}\text { Kontrol } \\
\text { positif }\end{array}$ & $\begin{array}{c}\text { Ekstrak } \\
2,5 \%\end{array}$ & $\begin{array}{c}\text { Ekstrak } \\
3,75 \%\end{array}$ & $\begin{array}{c}\text { Ekstrak } \\
5 \%\end{array}$ \\
\hline 0 & 0.00 & 0.00 & 0.00 & 0.00 & 0.00 \\
1 & 0.00 & 3.50 & 4.50 & 0.00 & 0.00 \\
2 & 0.00 & 11.50 & 6.00 & 8.00 & 5.00 \\
3 & 20.50 & 43.50 & 17.50 & 28.00 & 19.50 \\
4 & 41.50 & 81.00 & 39.50 & 53.50 & 44.50 \\
5 & 58.50 & 84.00 & 53.00 & 79.00 & 83.00 \\
6 & 71.00 & 100 & 79.50 & 95.00 & 89.00 \\
7 & 81.00 & 100 & 79.50 & 97.00 & 92.00 \\
8 & 87.00 & 100 & 87.50 & 97.00 & 92.00 \\
9 & 93.00 & 100 & 94.00 & 100 & 94.50 \\
10 & 93.50 & 100 & 100 & 100 & 100 \\
\hline
\end{tabular}

Perbedaan persentase penyembuhan luka sayat dapat dilihat pada gambar 4 . 


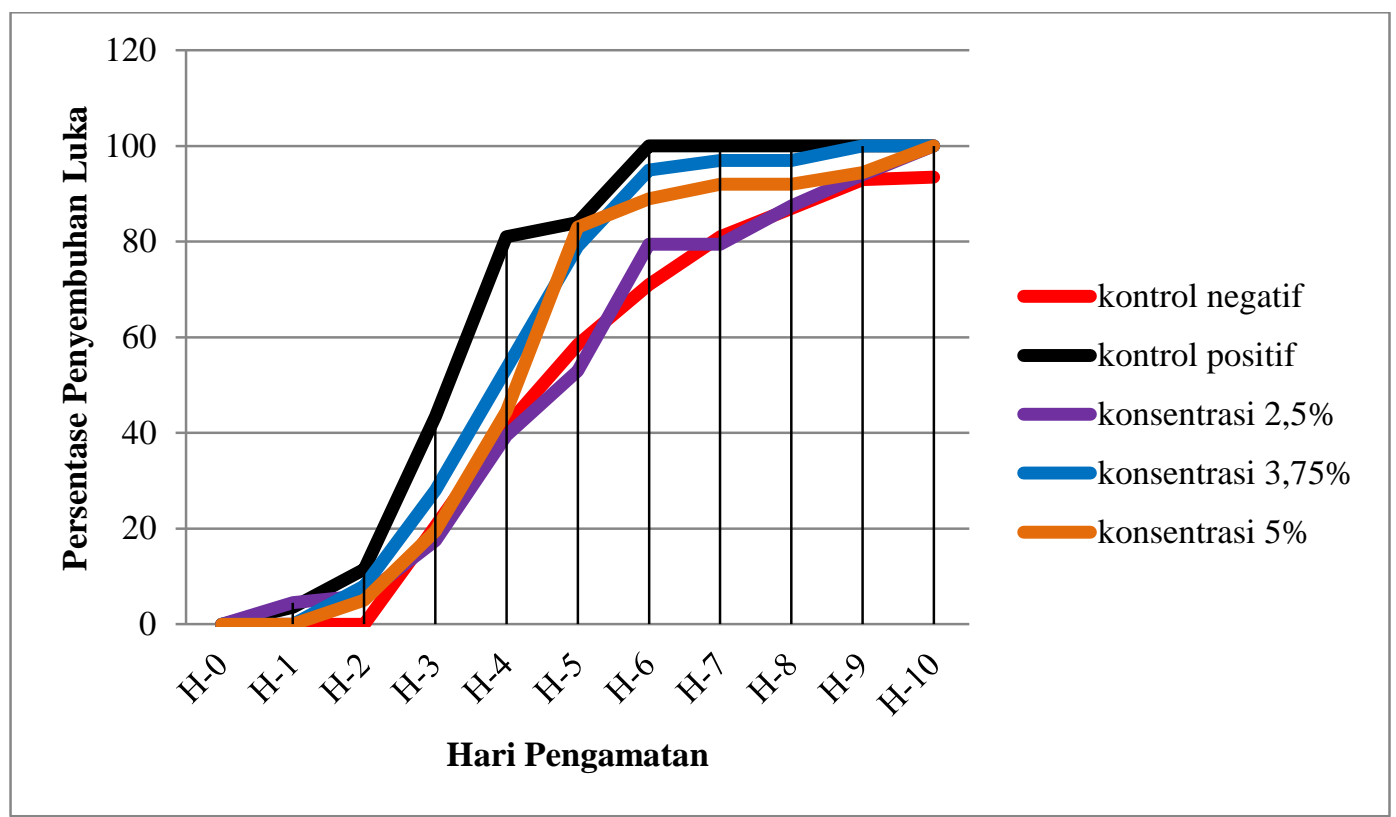

Gambar 4. Grafik Persen Kesembuhan Luka

Pengukuran rata-rata panjang luka pada tabel 1 untuk semua kelompok perlakuan pada hari ke-0 sampai ke-10 mengalami perubahan panjang luka. Dimana panjang luka berkurang paling signifikan pada konsentrasi 3,75\% yaitu di hari ke 9 dibandingkan dengan kelompok konsentrasi ekstrak yang lainnya. Artinya di dalam ekstrak buah pandan duri mengandung zat aktif yang mampu meningkatkan dan menstimulasi proses penyembuhan luka. Sebaliknya daya penyembuhan luka paling rendah terdapat pada luka dengan perlakuan pemberian Na CMC (kontrol negatif). Hal ini disebabkan karena tidak adanya pemberian obat atau zat yang berkhasiat dalam penyembuhan luka, hanya saja kelompok perlakuan ini tetap mengalami penyembuhan luka yang ditandai dengan perubahan panjang luka yang berangsur sembuh. Berdasarkan self healing power dimana tubuh mempunyai kemampuan untuk menyembuhkan diri sendiri (Ismalil, 2009).

Uji statistik ANAVA dilakukan untuk melihat apakah terdapat efek dari semua perlakuan terhadap penyembuhan luka. Hasil analisis menunjukkan nilai $\mathrm{F}$ hitung sebesar 3,902 dan F tabel 2,66. Sehingga $F$ hitung lebih besar dari F tabel $(3,902>2,66)$ yang dapat disimpulkan bahwa rata-rata panjang luka dari semua perlakuan hari ke-0 sampai hari ke-10 terdapat perbedaan yang signifikan dan terbukti secara sistematik.

Waktu penyembuhan luka pada ekstrak buah pandan duri relatif sama dengan kelompok kontrol positif, tetapi berbeda untuk kontrol negatif yang membutuhkan waktu penyembuhan luka lebih lama. Hal ini dipengaruhi oleh bahan aktif yang terkandung dalam buah pandan duri yaitu alkaloid,steroid dan fenol yang berguna sebagai antibakteri pada luka. Senyawa tersebut bekerja dengan menekan pertumbuhan bakteri patogen dan mencegah terjadinya infeksi pada luka sehingga kesembuhan luka dapat dipercepat. Aktivitas antimikroba dari ekstrak etanol buah pandan duri menurut beberapa penelitian diantaranya antibakteri terhadap bakteri Pseudomonas aeruginosa, Pseudomonas vulgaris dan Staphylococcus aureus serta aktivitas antijamur A. fumigates, Candida albicans dan Streptococcus creveceae.

Kelompok kontrol positif merupakan kelompok yang diberikan obat standar dalam penanganan luka yaitu Bioplacenton ${ }^{\circledR}$. Bioplacenton ${ }^{\circledR}$ merupakan obat topikal berbentuk gel yang dikemas dalam tube. Mengandung neomisisn sulfat $0,5 \%$ dan ekstrak plasenta $10 \%$. Ekstrak plasenta dapat menstimulasi terjadinya regenarasi sel, sedangkan neomisin sulfat 
dapat berperan sebagai bakteriosid. Ekstrak etanol buah pandan duri juga memiliki aktivitas mempercepat penyembuhan luka dibandingkan kontrol negatif, kemidian konsentrasi 3,75\% tidak berbeda signifikan dengan kontrol positif.

\section{KESIMPULAN}

1. Ekstrak etanol buah pandan duri memiliki persentase rendemen sebesar $17,62 \%$ dengan kandungan metabolit sekunder yaitu fenol, steroid dan alkaloid.

2. Ekstrak etanol buah pandan (Pandanus tectorius Soland) duri memiliki antivitas dalam penyembuhan luka pada tikus putih (Rattus norvegicus) dengan dosis efektif $3,75 \%$.

\section{DAFTAR PUSTAKA}

1. Depkes RI., 1979, Farmakope Indonesia Edisi III. Departemen Kesehatan Republik Indonesia. Jakarta.

2. Depkes RI., 2000, Parameter Standar Umum Ekstrak Tumbuhan Obat. Cetakan Pertama. Departemen Kesehatan Republik Indonesia. Jakarta.

3. WHO., 2008, World Report on Road Traffic Injury Prevention. Peden et al, World Health Organization, Geneva. Switzerland.

4. Xu, X., Zhang, X., Guo, P., Sun, G., Chen, S., Yang, M., Fu, N., Wu, H. 2012, Phenolic, compounds and flavonoids from the fruits of Pandanus tectorius Soland. $J$. Med. Plants Res. 6. 2622-2626

5. Sjamsuhidajat, R. dan Wim de Jong., 2004, Buku Ajar Ilmu Bedah Edisi 1. EGC. Jakarta.

6. Ismail, Gunawan., 2009, Sehat Tanpa Obat, "dengan tusuk jarum ala Indonesia”. Grasindo. Jakarta

7. Khond, Mangesh, J.D. Bhosale, Arif Tasleem, Mandal.T.K, Padhi, M.M, Dabur Rajesh., 2009, Screening of Some Selected Medicinal Plants Extracts for In-vitro Antimicrobial Antivity. Journal of Scientific Research 4.271-278 